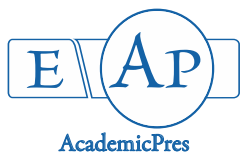

Nayak A (2021)

Notulae Scientia Biologicae 13(1):10871

DOI: $10.15835 / \mathrm{nsb} 13110871$

Research Article

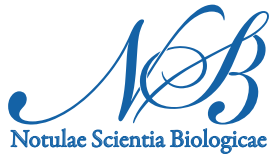

\title{
Nesting tree selection by scattered heronry birds of drought prone Northern Bankura, West Bengal, India: preference of Phoenix sylvestris near wetland-associated habitats
}

\author{
Ananya NAYAK \\ Bankura Sammilani College, Department of Zoology, Kenduadihi 722102, Bankura, West Bengal, India; ananya001@gmail.com
}

\begin{abstract}
The present study was conducted in the Gangajalghati block of Northern Bankura, India, to investigate the habitat and nest tree preference of three colonial waterbirds viz. Nycticorax nycticorax, Egretta garzetta, and Ardeola grayii. The study sites were surveyed for 20 months between 2017 and 2020. A total of 817 nests with an average of 204 per year were recorded on 13 tree species. Nycticorax nycticorax showed the maximum nest count followed by Egretta garzetta and Ardeola grayii. Relative abundance data revealed Phoenix sylvestris as the most abundant species (45\%) of the area and harbours the highest proportion (33\%) of nests. Pooled nest count data showed significantly higher $(\mathrm{p}<0.01)$ total nest counts in the wetland associated habitats than others. The study observed more nest density of all three species near a cluster of small ponds than in a large water body. Year-wise difference in cumulative nest number and mean nest abundance of all three species was statistically insignificant. The interspecific nearest neighbour on Phoenix sy/vestris were Egretta garzetta (88.37\%) for Nycticorax nycticorax and Nycticorax nycticorax (83.25\%) for Egretta garzetta and Ardeola grayii. Further, the study evaluated the impact of two tropical cyclones (Amphan and Fani) on the total nest count and found that more than $75 \%$ nests $(\mathrm{p}<0.05)$ were destroyed by the mighty Amphan in May 2020. The study provides a baseline data on nesting trees and habitat preference of three species of heronry birds from Northern Bankura.
\end{abstract} wetland

Keywords: Amphan; Bankura; Gangajalghati; nesting tree; Nycticorax nycticorax, scattered heronry;

Abbreviations: AG-Ardeola grayii; EG-Egretta garzetta; GPS-Global Positioning System; NNNycticorax nycticorax; OTH-Other Habitat; WL-Wetland Associated Habitat

\section{Introduction}

Heronry is a breeding colony of one or more species of water birds that usually exhibit group nesting in a group of trees and shows spatial and temporal clumping of nests during the breeding season (Roshnath et al., 2019). These may include colonial water birds like herons, egrets, storks, pelicans, ibises, spoonbills, darter, cormorants, and other species which play an important role in agricultural ecosystem and help in pest control, nutrient cycling as well as regulation of fish population (Roshnath and Sinu, 2017; Roshnath et al., 2017). Further, being one of the top carnivores in the aquatic food chain, these colonial waterbirds can serve as

Received: 25 Dec 2020. Received in revised form: 04 Feb 2021. Accepted: O8 Feb 2021. Published online: 10 Feb 2021.

From Volume 13, Issue 1, 2021, Notulae Scientia Biologicae journal will use article numbers in place of the traditional method of continuous pagination through the volume. 
potential bioindicators and can help us to predict environmental changes at an aquatic ecosystem (Kushlan, 1993). Habitat wise studies on colonial waterbird nesting sites have found that nearly $53 \%$ of the existing nesting sites are located within or close to human habitation and only a small proportion of the existing heronries are found in protected areas in India (Subramanya, 1996).

A total of 26 species of colonially nesting waterbirds have been reported from India which form heronries usually close to water (Subramanya, 1996; Narayanan et al., 2012). Several studies have reported the breeding biology of these heronry birds including their breeding ecology and nesting tree characteristics in different ecosystems of India (Datta and Pal, 1993; Subramanya, 1996; Subramanya, 2005; Gopi and Pandav, 2011; Jha, 2012; Narayanan et al., 2012, Roshnath and Sinu, 2017; Roshnath et al., 2017; Chakraborty and Majumder, 2018; Roshnath et al., 2019).

The state of West Bengal represents one of the least heronry rich states in India having less than ten existing sites with Sajnakhali Wildlife Sanctuary and Raiganj Wildlife Sanctuary being the prominent two such sites (Datta and Pal, 1993; Subramanya, 1996). While the vast majority of studies on heronry have been conducted from the Raiganj and Sajnakhali Wildlife Sanctuaries of West Bengal (Law, 1951; Mukhopadhyay, 1959; Chaudhari and Chakrabarti, 1973; Mukhopadhyay, 1980; Datta and Pal, 1990; Sharma 1998, 2001, 2004; Sridhar, 2004; Jha, 2006; Sharma 2007a, 2007b; Pramanik et al., 2009, 2014, 2016) only a few studies have attempted to determine the status of these birds from other parts of the state (Law, 1926; Dhua et al., 2013; Mondal et al., 2014; Chakraborty and Majumder, 2018). Moreover, majority of these studies were carried out on the Asian openbill Anastomus oscitans, Boddaert, 1783 (Law, 1926; Mukhopadyaya, 1980; Sharma 1998, 2001; Sharma, 2007a; Dhua et al., 2013; Pramanik et al., 2009, 2014, 2016). Only two studies have conducted preliminary investigations on Anastomus oscitans, Boddaert, 1783 and Leptoptilos javanicus, Horsfield, 1821 in the Bankura district of West Bengal (Dhua et al., 2013; Mondal et al., 2014). Nest-site selection in birds is a complex decision-making process which is crucial to offspring production and therefore has a vital role in reproductive success and fitness (Fogarty et al., 2017; Podkowa and Surmacki, 2017). Several factors influence the selection of nest sites in colonial birds including nest site availability, food availability, proximity of feeding areas, camouflage and protection against predators, illumination in nest site, relative position of the nest within the colony and distance to neighbouring nests (Cuervo, 2004; Podkowa and Surmacki, 2017). No comprehensive study has been conducted to date to elucidate the nesting tree selection of other heronry birds from any part of Bankura. The present study was conducted in the Gangajalghati block of Northern Bankura to investigate the habitat and nest tree preference of three colonial waterbirds viz. Nycticorax nycticorax, Linnaeus, 1758; Egretta garzetta, Linnaeus, 1766 and Ardeola grayii, Sykes, 1832. The study has also recorded the impact of two extremely powerful and catastrophic tropical cyclones (Fani and Amphan) on the active nests of these birds in the region. The study embodies 4 years' observations (2017-2020) on the nest tree and habitat preference of these heronry birds in Gangajalghati block of Bankura district.

\section{Materials and Methods}

\section{Studyarea}

The present study was conducted in 21.5 -hectare $\left(215000 \mathrm{~m}^{2}\right)$ heronry situated in seven different locations (Table 1) of Gangajalghati community development block in the northern part of Bankura District, West Bengal, India (Figure 1). These seven locations cover about 25 square kilometres of Gangajalghati community development block. Some of the notable landforms surrounding the study area are Gangajalghati forest on the North, Damodar River $(18 \mathrm{~km}$ ) on the North and Northeast, Koro hill (400 feet, $5 \mathrm{~km}$ ) and Sali River $(5 \mathrm{~km})$ on the South, Sali Reservoir or Gangdua Dam $(4 \mathrm{k} . \mathrm{m})$ on the Southwest and Susunia hill $(1,470$ feet, $18 \mathrm{~km}$ ) on the West. Among these Koro hill, Sali River and Sali Reservoir constitute three of the seven study sites (Table.1). The study area encompasses a diverse range of habitats (Figure 2) such as a large number of freshwater ponds (31), river bank (Sali), a small hill (Koro), a dam (Sali Reservoir), a canal originated from 
the Sali reservoir, agricultural fields, scattered trees and scrub vegetation (Table 1). Sali reservoir or Gangdua $\operatorname{dam}\left(23.40^{\circ} \mathrm{N}\right.$ and $\left.87.08^{\circ} \mathrm{E}\right)$, constructed on river Sali is the second largest dam in the district with a length of 1494 meters and serves for local farmland irrigation and a drinking water supply project (Nayak, 2019). The topography of the block has been described as an undulating plain with irregular hillocks and lateritic upland with numerous fault and joint structures in the pediments (Das and Gupta, 2019). Gangajalghati block is a sub topical climate region that exhibits high temperatures $\left(35-45^{\circ} \mathrm{C}\right)$ during summer season and about $12-15^{\circ} \mathrm{C}$ in the winter season (Das and Gupta, 2019). However, the maximum temperature sometimes may reach up to $48{ }^{\circ} \mathrm{C}$ and minimum temperature sometimes may go down to as low as $5-7^{\circ} \mathrm{C}$. The pre-monsoon months (March-May) experience frequent Nor'westers (Kal Baisakhi-a short-lived dusty squall at the onset of the southwest monsoon) with strong winds and heavy rainfall creating a destructive phenomenon leading to severe destruction over the area through which it passes (Chakrabarty et al., 2007). The region experiences an annual average rainfall of $1350 \mathrm{~mm}$ and the monsoon season (June to September) contributes approximately $80 \%$ of the total rainfall (Das, 2017). Trees occur in scattered patches throughout the landscape interspersed with scrub vegetation which are more densely distributed near wetland associated areas (Table 3). Some other common plants of the area are Acaciasp, Aegle marmelos, Argemone mexicana, Borassus flabellifer, Calotropis gigantea, Carica papaya, Clerodendrum infortunatum, Colocasia esculenta, Datura sp., Haldina cordifolia, Justicia adhatoda, Moringa oleifera, Musa paradisiaca, Opuntia spp, Psidium guajava, Ricinus communis etc. Paddy is the principal crop of the area with some common vegetables being Brinjal, Cabbage, Cauliflower, Potato, Onion, Radish, Tomato e.t.c).
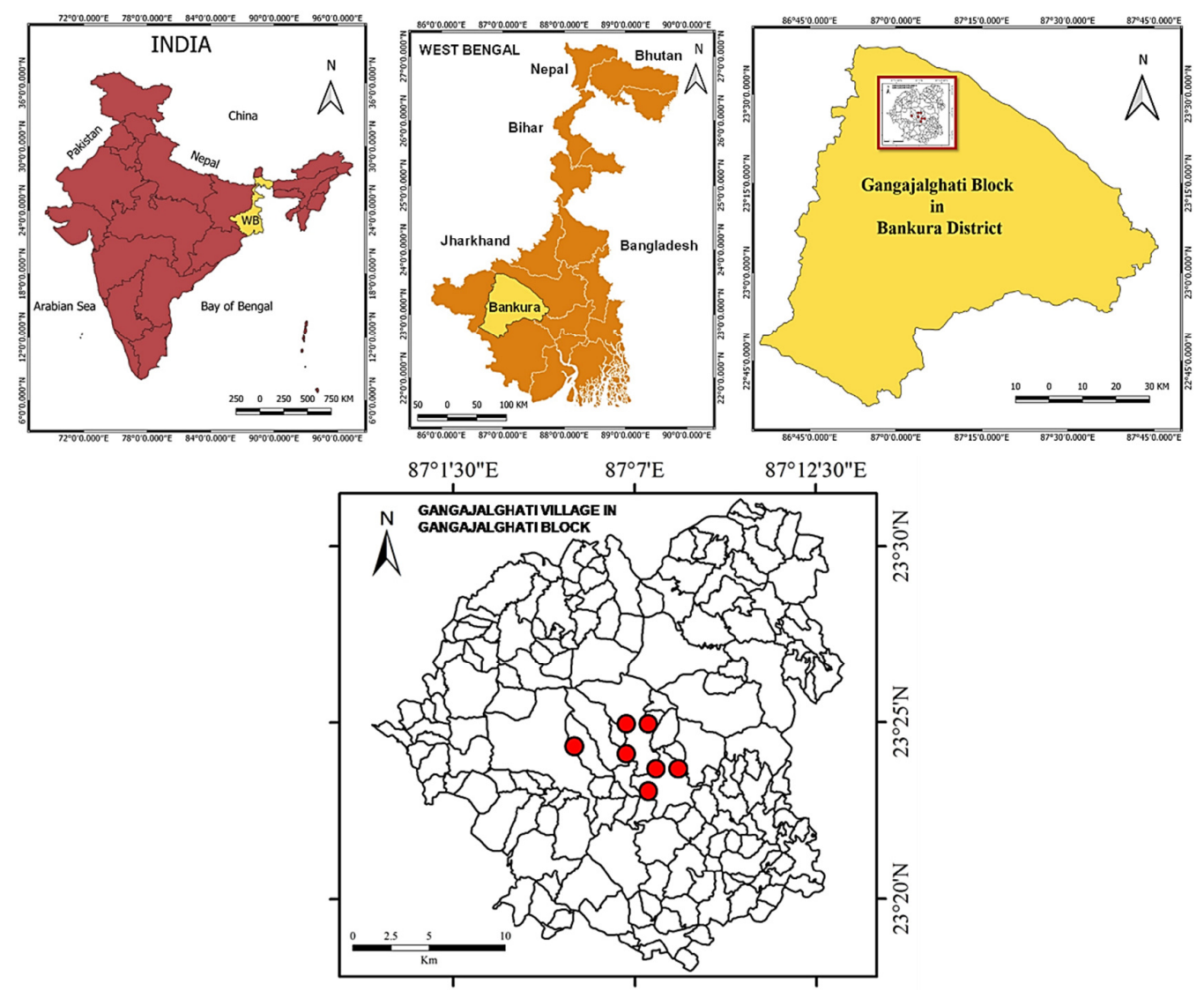

Figure 1. Geographical location of the study area: Seven study sites in Gangajalghati block of Bankura district, West Bengal, India

(Map data: India and West Bengal from Nayak, 2020 with permission from the publisher; Bankura district was generated using QGIS; Gangajalghati Block modified after Das, 2017). 
Nayak A (2021). Not Sci Biol 13(1):10871

Table 1. The GPS coordinates and altitudes of the seven study sites located in the Gangajalghati block

\begin{tabular}{|c|c|c|c|c|c|c|}
\hline $\begin{array}{c}\text { Sl. } \\
\text { No }\end{array}$ & $\begin{array}{c}\text { Locality of } \\
\text { sampling sites }\end{array}$ & $\begin{array}{c}\text { GPS } \\
\text { coordinate }\end{array}$ & Altitude & $\begin{array}{c}\text { Area } \\
\text { studied } \\
\text { hectare })\end{array}$ & Habitat type & $\begin{array}{c}\text { Number of } \\
\text { Wetlands }\end{array}$ \\
\hline 1 & Bhairabpur village & $\begin{array}{c}23.399978, \\
87.108305\end{array}$ & 110 meters & 1.5 & Human Habitation & Pond (3) \\
\hline 2 & Gangdua Dam & $\begin{array}{c}23.406043, \\
87.086375\end{array}$ & 107 meters & 8 & $\begin{array}{c}\text { Barren Land, } \\
\text { Agriculture Land and } \\
\text { Eucalyptus plantations }\end{array}$ & $\begin{array}{c}\text { Pond (2), } \\
\text { Rervoir (1) Canal }(1)\end{array}$ \\
\hline 3 & Kapista Village & $\begin{array}{c}23.385764, \\
87.137337\end{array}$ & 105 meters & 1.5 & Human Habitation & Pond (7) \\
\hline 4 & Koro Hill & $\begin{array}{c}23.388551, \\
87.115815\end{array}$ & 98 meters & 2.5 & Agriculture Land & Pond (6) \\
\hline 5 & Nayak Para Durga & $\begin{array}{c}23.417739, \\
87.115170\end{array}$ & 120 meters & 2.5 & Human Habitation & Pond (7) \\
\hline 6 & Purano Bandh & $\begin{array}{c}23.421461, \\
87.112079\end{array}$ & 118 meters & 2 & $\begin{array}{c}\text { Agriculture Land and } \\
\text { Human Habitation }\end{array}$ & Pond (5) \\
\hline 7 & Sali River Bridge & $\begin{array}{c}23.381505, \\
87.114871\end{array}$ & 95 meters & 3.5 & Agriculture Land & $\begin{array}{c}\text { Pond (1) and } \\
\text { River }(1)\end{array}$ \\
\hline
\end{tabular}
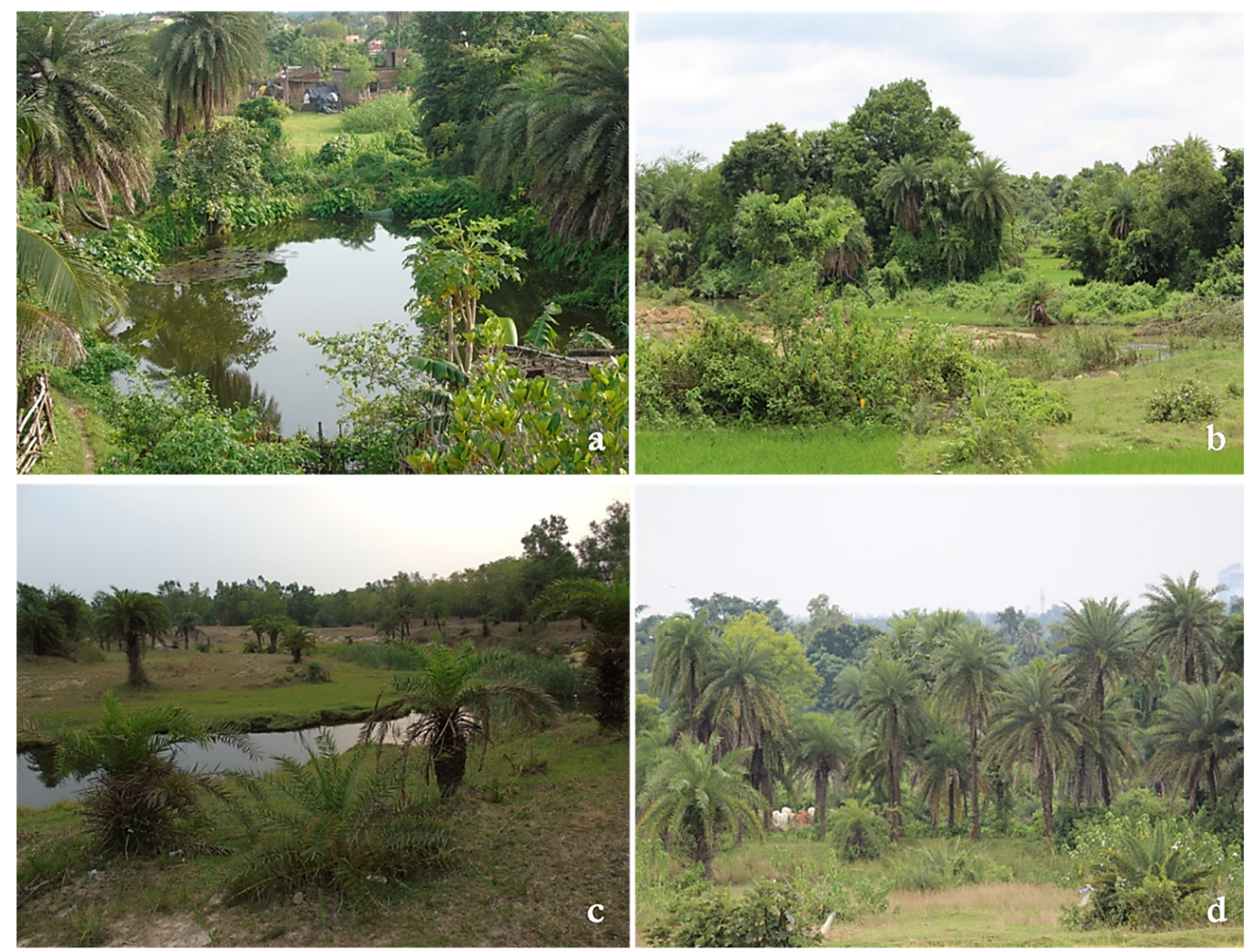

Figure 2. Different types of habitats found within the study area, Gangajalghati block

a. A pond surrounded by Indian date palm trees in Gangajalghati village; b. Vegetation around Sali river; c. Habitat around Gangdua dam \& d. A colony of Phoenix sy/vestris near Koro hill. 


\section{Field methods}

The above-mentioned study sites (Table 1) of Gangajalghati block were surveyed for 20 months between 1 May 2017 and 30 September 2020. The observations were carried out for four seasons (May to September) during the entire survey period to study the nesting tree preferences of three colonial waterbird species viz. Nycticorax nycticorax, Linnaeus, 1758; Egretta garzetta, Linnaeus, 1766 and Ardeola grayii, Sykes, 1832. Each study site was divided into two zones, wetland associated habitat (WL), located within 10 meters of a water body and others $(\mathrm{OTH})$ that are located beyond the range. The birds and their nests were observed using a binocular (Olympus 10 x 50 DPS) and photographed using a Canon EOS 1200D DSLR Camera with a 55$250 \mathrm{~mm}$ lens and a Sony DSC-H400 compact camera with 63x Optical Zoom to support further identification. The birds were identified using standard field guides (Ali and Ripley, 1987; Grimmett et al., 2011). Nesting locations were also recognised through chick's call even at night hour. In order to document total number of bird nests in every season, each study site was visited thrice in a month and the number of nests of each species and their nearest nest neighbour were recorded. Calculation of nearest nest neighbour distance was done according to the method of Brown and Brown, 2000. However, the study recorded nearest nest neighbour in four (Phoenix sylvestris, Azadirachta indica, Terminalia arjuna, Tamarindus indica) tree species out of 13 species studied (Table 2) and did not record the number of eggs, hatchlings or number of chicks fledged successfully per nest. Tree characteristics (species, height, distance from water body) and nest height from the ground of some (nests on Phoenix sylvestris and Azadirachta indica) of the heronries from the study site were recorded. A graded pole $(1 \mathrm{~m})$ was used to measure the tree height (Roshnath and Sinu, 2017). To avoid disturbance during breeding season, measurements of tree height were carried out in non-breeding period (March and April of each season). To determine the impact of cyclone Fani and Amphan on the nest numbers, total number of nests recorded from four (Phoenix sylvestris, Azadirachta indica, Terminalia arjuna, Tamarindus indica) tree species before and after (for the next three days) the cyclones were compared. None of the species was captured or killed during the entire period of the study.

Table 2. Three species of heronry birds and their nest number observed in the study area

\begin{tabular}{|c|c|c|c|c|c|c|}
\hline Family & Common name & Scientific name & \multicolumn{4}{|c|}{ No. of nests } \\
\hline & & & 2017 & 2018 & 2019 & 2020 \\
\hline \multirow{3}{*}{ Ardeidae } & Little egret & Egretta garzetta & 74 & 92 & 71 & 78 \\
\hline & Black-crowned night heron & Nycticorax nycticorax & 117 & 130 & 94 & 56 \\
\hline & Indian pond-heron & Ardeola grayii & 33 & 30 & 25 & 17 \\
\hline \multicolumn{3}{|l|}{ Total } & 224 & 252 & 190 & 151 \\
\hline
\end{tabular}

\section{Statistical analysis}

Statistical data analysis and graphical representations of data except post-hoc Tukey HSD (honestly significant difference) were performed using Microsoft Office Excel, 2010. To compare relative nesting tree preference (Figure 5A), relative habitat preference (Figure 5B) and effect of cyclone Amphan and Fani on the nest number (Figure 8) one-way analysis of variance (ANOVA) using means of group data was conducted setting Alpha to 0.05. Tukey's HSD post hoc analysis between pairs or subgroups after a significant ANOVA result, was performed using Tukey HSD calculator (astatsa.com) to identify specific variables that differ significantly. 


\section{Results}

The present work recorded a total of three species of heronry birds belonging to family Ardeidae and order Pelecaniformes (Figure 3). A total of 817 nests with an average of 204 per year were recorded during the entire study period (Table 2). The study observed heronries only on 13 tree species (Table 3). A total of 841 trees of 13 species were examined and nearly 55\% of them harboured heron rookeries. Majority of the heronries were scattered across seven different locations in the close vicinity of human habitation with diffuse vegetation and several ponds. A one-way ANOVA $(\mathrm{F}=64.11, \mathrm{p}<0.001)$ of pooled nest count of the two habitat types followed by a Tukey's HSD test $(\mathrm{p}<0.01)$ showed a significant difference between the total nest counts in the wetland associated (WL) and other habitats (OTH) (Figure 5B). These findings are consistent with the previous studies that showed increased nest occurrence at colony sites near wetland habitats (Kelly et al., 2008; Roshnath and Sinu, 2017; Chakraborty and Majumder, 2018). The study observed more heronry bird nests (data not shown) of all three species near study sites with a cluster of small ponds rather than in area with scattered or large water body (Sali Reservoir). The highest number of nests were recorded in the Gangajalghati village study sites (Nayak Para Durga Bari and Purano Bandh) having 11 small and a large pond in cluster. Previous studies have shown that a group of small wetlands with higher habitat heterogeneity can harbour more waterbird species than a larger one with equivalent area (Brown and Dinsmore, 1986; Scheffer et al., 2006; Ma et al., 2010). Further, the study has observed more nesting in the trees on the narrow pond dykes surrounded by other ponds or scrub vegetation. This type of habitat reduces human disturbances and predator attack. Moreover, small sized pond makes it easy for foraging and meeting the other requirements for different waterbird species (Ma et al., 2010).
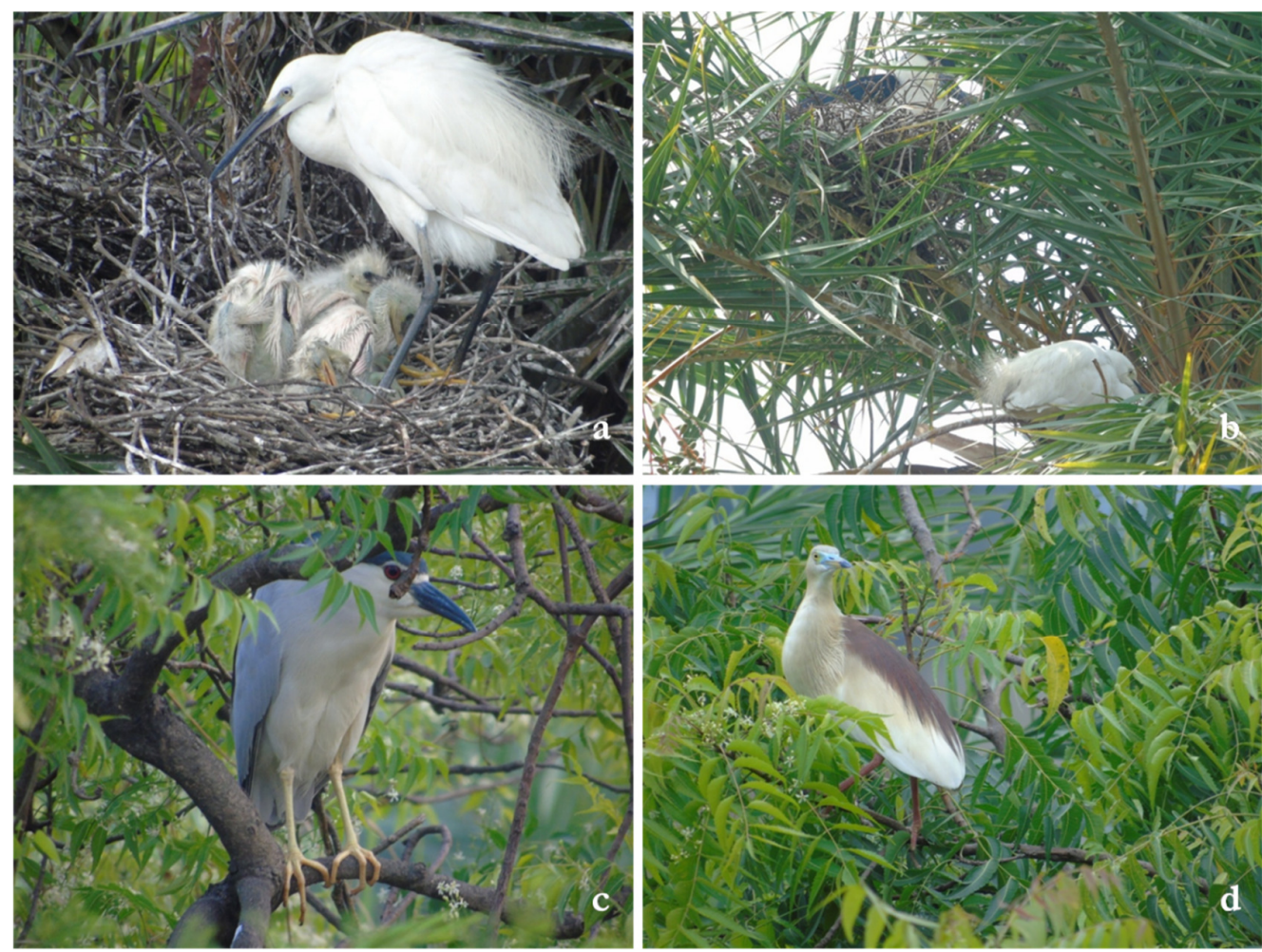

Figure 3. Three species of heronry birds surveyed in the study area

1. A little egret guarding the nest on an Indian date palm tree (Phoenix sy/vestris); b. Nearest neighbours, above: A black-crowned night heron guarding the nest on a date palm tree, below: A little egret guarding the nest on the same tree; c. A black-crowned night heron sitting near the nest on a Neem tree (Azadirachta indica); d. An Indian pond-heron in breeding plumage sitting near the nest on a Neem tree. 
Table 3. Summary of number, height of nesting trees of different species and nest numbers (mean \pm SD) per tree recorded during four years (2017 to 2020) in the study area

\begin{tabular}{|c|c|c|c|c|c|c|c|c|}
\hline $\begin{array}{c}\text { Sl. } \\
\text { No }\end{array}$ & Common name & Scientific name & $\begin{array}{c}\text { Mean tree } \\
\text { number }\end{array}$ & SD & $\begin{array}{c}\text { Mean tree } \\
\text { height }(\mathrm{m})\end{array}$ & SD & $\begin{array}{c}\text { Mean nest } \\
\text { number }\end{array}$ & SD \\
\hline 1 & Indian date palm & Phoenix sylvestris & 52.5 & 12.12 & 6.32 & 1.10 & 68.25 & 17.19 \\
\hline 2 & Neem & Azadirachta indica & 10.25 & 0.95 & 7.98 & 1.12 & 33.5 & 10.47 \\
\hline 3 & Bamboo & Bambusa sp. & 9 & 0.81 & 7.6 & 1.36 & 8.5 & 3.10 \\
\hline 4 & Arjun & Terminalia arjuna & 5.5 & 1.29 & 8.75 & 0.83 & 21.25 & 3.59 \\
\hline 5 & Tamarind & Tamarindus indica & 5.5 & 1.29 & 10.47 & 1.25 & 14.75 & 4.03 \\
\hline 6 & Toothbrush tree & Streblus asper & 5.5 & 1.29 & 5.45 & 0.73 & 8.75 & 2.06 \\
\hline 7 & Coconut & Cocos nucifera & 4.75 & 1.25 & 11.36 & 0.93 & 5.75 & 2.06 \\
\hline 8 & Cotton tree & Bombax ceiba & 4.75 & 1.5 & 10.97 & 0.79 & 9.5 & 1.91 \\
\hline 9 & Banyan & Ficus benghalensis & 4.5 & 1.29 & 8.78 & 0.9 & 7.75 & 1.25 \\
\hline 10 & Jamun & Syzygium cumini & 3.75 & 0.95 & 9.55 & 1.26 & 10.75 & 4.85 \\
\hline 11 & Sacred fig & Ficus religiosa & 3.75 & 1.25 & 10.82 & 0.82 & 9.75 & 2.62 \\
\hline 12 & Chakalta & Adina cordifolia & 3.5 & 2.64 & 7.02 & 2.17 & 3.5 & 3 \\
\hline 13 & Gamhar & Gmelina arborea & 2.75 & 1.89 & 7 & 2.33 & 2.25 & 1.5 \\
\hline
\end{tabular}

$\mathrm{SD}=$ Standard Deviation

Relative abundance data for nesting trees recorded in the study sites revealed Phoenix sylvestris as the most abundant (45\%) species followed by Cocos nucifera, Azadirachta indica, Bambusa sp. and others (Figure 4A). The results of relative nest abundance per tree showed that Phoenix sylvestris harbours the highest proportion (33\%) of nests followed by Azadirachta indica, Terminalia arjuna, Tamarindus indica and others (Figure $4 \mathrm{~B}$ ). Similar results were obtained in the cumulative nest numbers documented in each tree species (Figure 5A). A one-way ANOVA $(\mathrm{F}=13.52, \mathrm{p}<0.00001)$ and Tukey's HSD test $(\mathrm{p}<0.01)$ revealed that Phoenix sylvestris harboured significantly $(\mathrm{F}=13.52, \mathrm{p}<0.00001)$ higher number of nests in comparison to the other trees (Figure 5A).
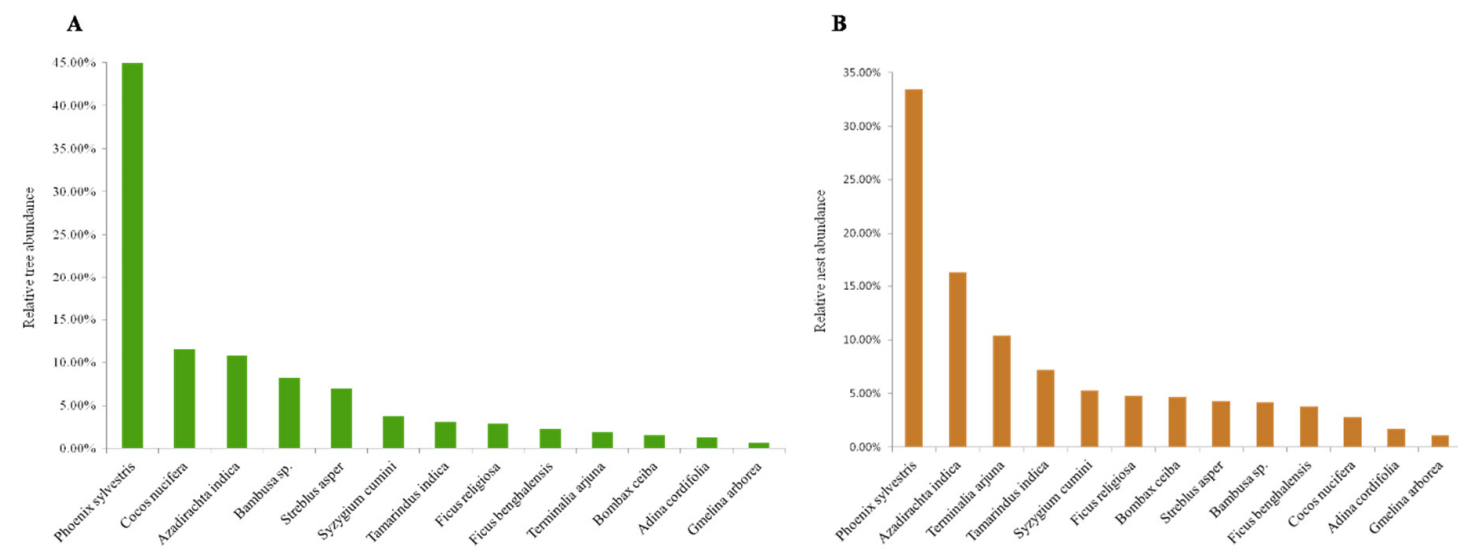

Figure 4. Histograms representing: A. relative tree abundance and B. relative nest abundance recorded in the seven study sites of Gangajalghati block 

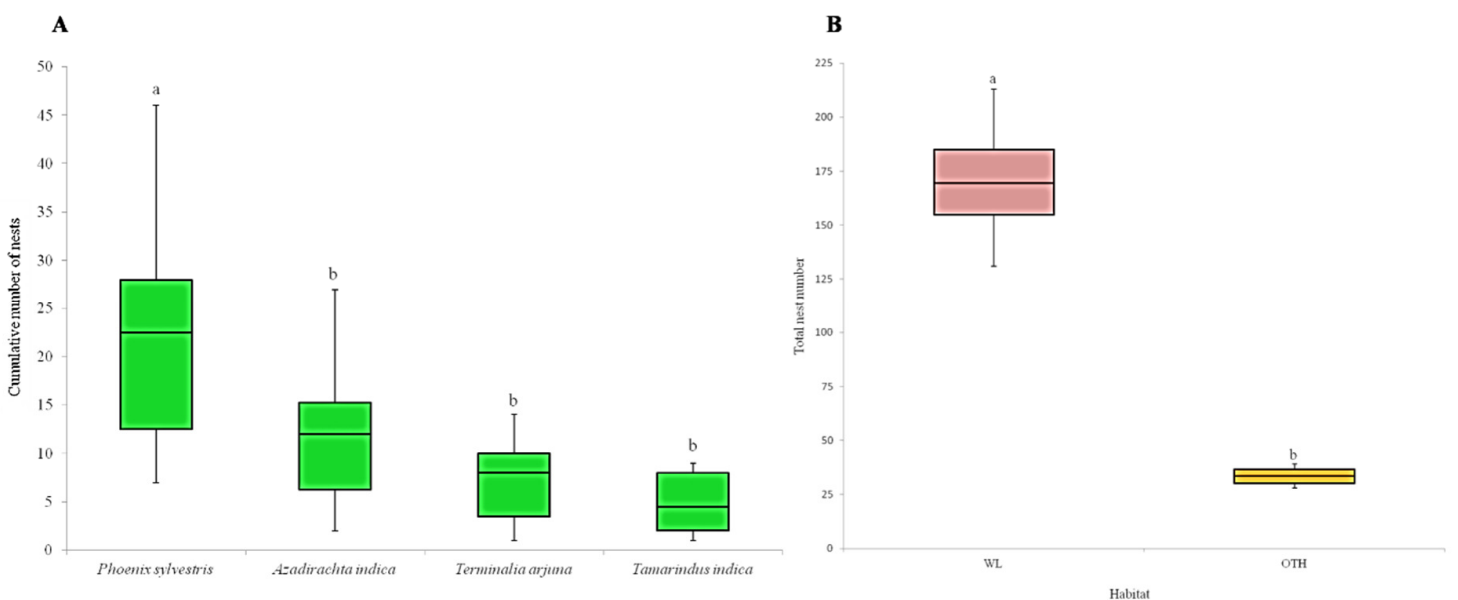

Figure 5. Box plots representing A. Tree-wise cumulative nest number and B. Habitat-wise total nest number recorded during the present study in four tree species

Each box plot shows minimum, lower quartile, median, upper quartile, and maximum values. Mean values were compared using one-way ANOVA with pair-wise comparisons made with Tukey's HSD (honestly significant difference) tests. Nest number recorded in four trees: Phoenix sylvestris, n=273; Azadirachta indica, n=134; Terminalia arjuna, $\mathrm{n}=85$ and Tamarindus indica, $\mathrm{n}=59$. Groups not sharing lowercase letters are significantly different (Tukey's HSD test, $\mathrm{p}<0.01$ ). WL=Wetland associated habitats, OTH=Other habitats.

The results of year-wise cumulative trend of nest number (Figure 6A) revealed a considerable difference in the nest number of all three species in each year. However, the difference was statistically insignificant $(\mathrm{p}>$ 0.05 ) as indicated by the results $(\mathrm{F}=0.3902)$ of one-way ANOVA (results not shown). Similar results were also obtained in the year-wise mean nest abundance of three different species (Figure 6B). The lowest cumulative nest number and mean nest abundance of 2020 could be partially attributed to the extensive nest damage caused by the tropical cyclone Amphan at the beginning (May) of their breeding season.
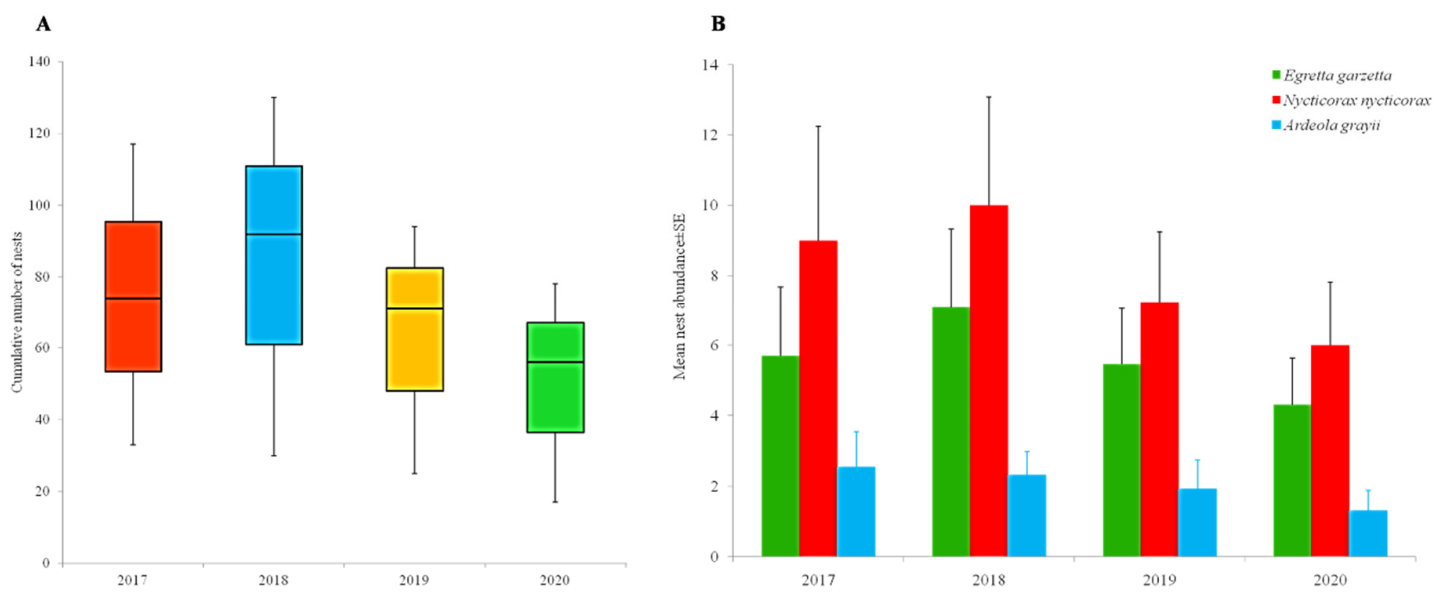

Figure 6. A. Box plots representing year-wise cumulative nest number and B. Histograms representing year-wise mean nest numbers of all three species

Nest numbers were recorded for 20 months between 1 May 2017 and 30 September 2020 from 13 tree species. Each box plot represents minimum, lower quartile, median, upper quartile, and maximum values. In both the cases, the mean values were compared using one-way ANOVA with pair-wise comparisons. However, the differences were statistically insignificant $(\mathrm{p}>0.05)$. SE=standard error. 
The present study also estimated the cumulative percentage of nearest neighbours of these three birds in four (Phoenix sylvestris, Azadirachta indica, Terminalia arjuna, Tamarindus indica) tree species from the study area (Figure 7). However, the survey recorded only interspecific nearest neighbours and conspecific neighbours were excluded from the calculation. In Phoenix sylvestris most black-crowned night heron nests (88.37\%) had little egret as their nearest neighbour, followed by Indian pond-heron (11.62\%). However, most little egret nests $(83.25 \%)$ had black-crowned night heron as their nearest neighbour, followed by Indian pondheron $(16.75 \%)$ and most Indian pond-heron nests $(83.25 \%)$ had black-crowned night heron as their nearest neighbour, followed by little egret $(16.75 \%)$ (Figure $7 \mathrm{~A})$. Similar results were also observed among neighbouring nests of the three birds on Azadirachta indica, Terminalia arjuna and Tamarindus indica (Figure 7B-D). Further, in all the trees studied, black-crowned night herons placed their nests higher in the canopy than little egrets and Indian pond-herons. These results are consistent with several prior studies that observed black-crowned night herons to build their nests higher in the canopy (Kazantzidis et al., 1997; Li et al., 2006).

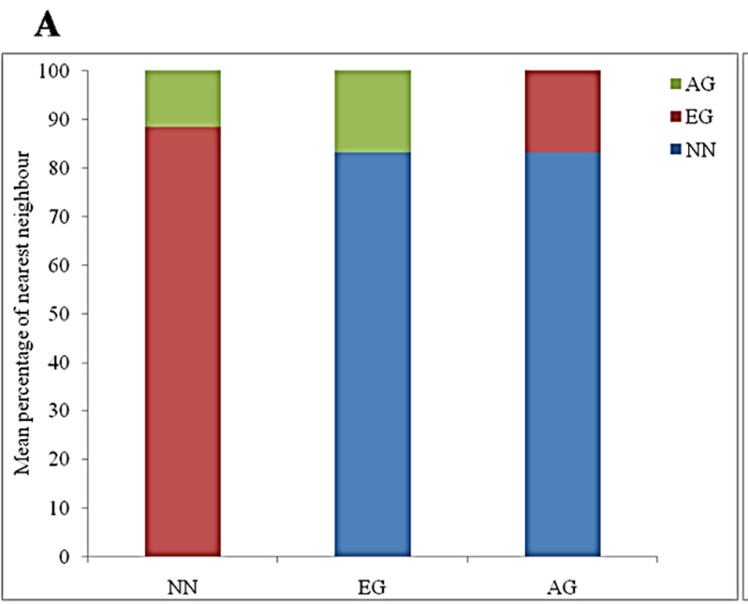

\section{B}

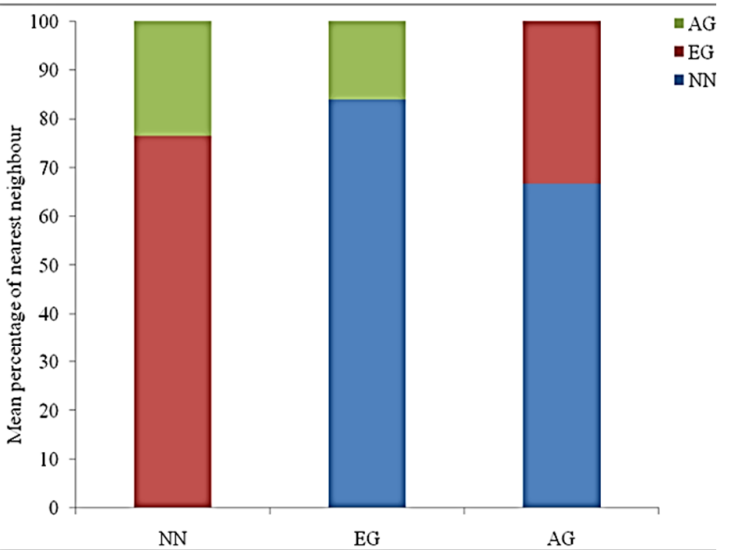

\section{C}

D

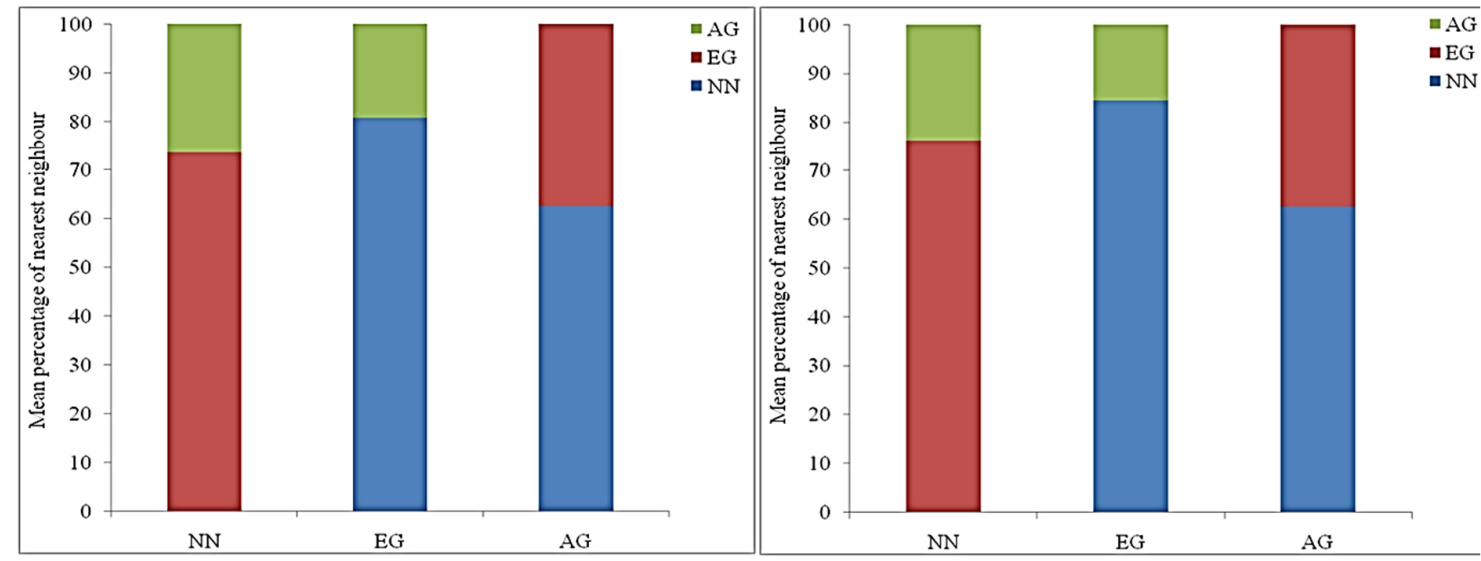

Figure 7. Histograms representing mean percentage of interspecific nearest neighbours of all three species $\mathrm{NN}=$ Nycticorax nycticorax, $\mathrm{EG}=$ Egretta garzetta, $\mathrm{AG}=$ Ardeola grayii. Nest number was documented in four plant species: Phoenix sylvestris, $\mathrm{n}=273$; Azadirachta indica, $\mathrm{n}=134$; Terminalia arjuna, $\mathrm{n}=85$ and Tamarindus indica, $\mathrm{n}=59$.

Finally, the study evaluated the impact of two tropical cyclones (Amphan and Fani) on the nesting of these three bird species. In 2019, Fani hit the study area at the midnight of 3rd May and caused a loss of 30\% of total nests of all three species (Figure 8B). However, the damage was statistically insignificant $(\mathrm{p}>0.05)$ as indicated by the results $(\mathrm{F}=0.9678)$ of one-way ANOVA (Figure 8B). A massive nest destruction was recorded 
by the impact of the catastrophic tropical cyclone Amphan that hit the study area on May 20 in 2020 (Figure $8 \mathrm{~A})$. More than $75 \%$ nests were destroyed by the mighty storm that hit the state capital Kolkata with a wind speed of 112-130 kmph along with heavy rain. The percentage of cumulative nest loss by Amphan was significantly higher than before the cyclone as revealed by the one-way ANOVA $(\mathrm{F}=9.07, \mathrm{p}<0.05)$ and Tukey's HSD test $(\mathrm{p}<0.05)$ (Figure 8A). Further, the cyclone resulted substantial damage to some of the remaining nests. However, the extent of such damage was not determined in the present study. Although a huge negative impact on nest number was recorded by the strike of Amphan and Fani, the study did not find any uprooted nesting tree caused by the two cyclones. The deep root systems of the nesting trees might have a key role in protection of these trees from the powerful tropical cyclones and Nor'westers. Studies have shown that tree species adapted to drought-prone regions generally have higher root-to-shoot ratios and deeper root systems than species occurring in the mesic climatic conditions (Brunner et al., 2015).
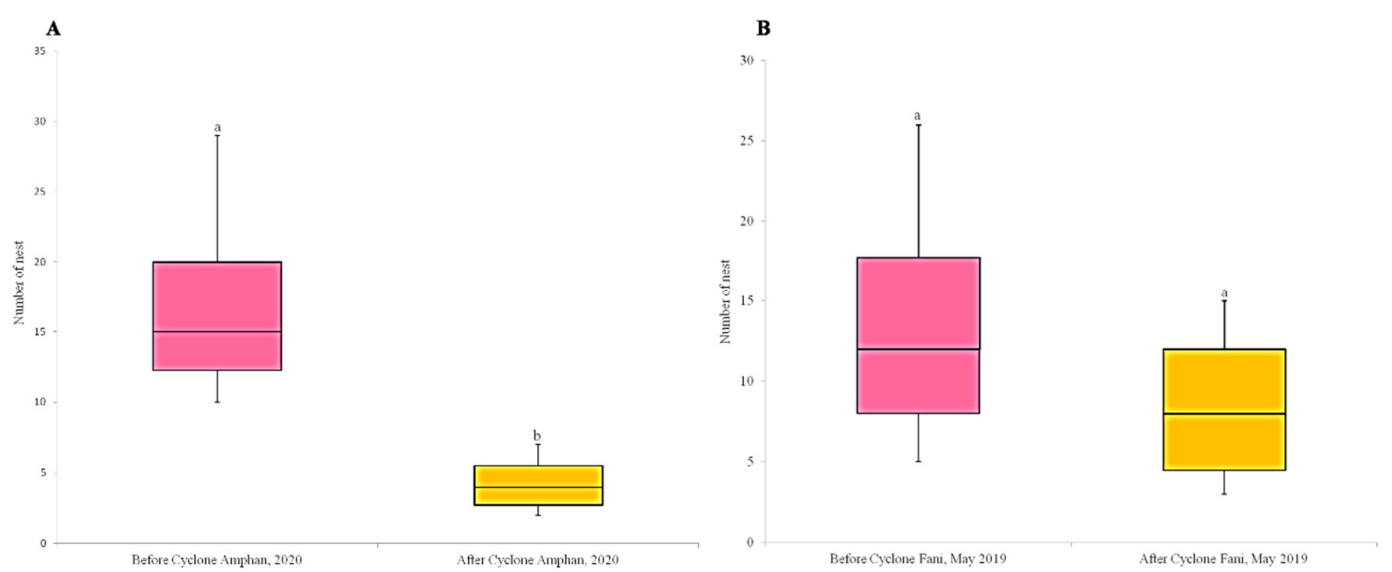

Figure 8. Box plots representing the effect of tropical cyclones A. Amphan and B. Fani on total nest count Each box plot shows minimum, lower quartile, median, upper quartile, and maximum values. Mean values were compared using one-way ANOVA with pair-wise comparisons made with Tukey's HSD (honestly significant difference) tests. Nests were recorded in four trees: Phoenix sylvestris, $\mathrm{n}=273$; Azadirachta indica, $\mathrm{n}=134$; Terminalia arjuna, $\mathrm{n}=85$ and Tamarindus indica, $\mathrm{n}=59$. Groups not sharing lowercase letters are significantly different (Tukey's HSD test, $\mathrm{p}<0.05)$.

\section{Discussion}

Although several studies have reported the preference of these herons toward urban environment, a considerable population still enjoys the rural habitat (Subramanya, 1996). A recent study (Roshnath et al., 2019) in India has shown that these birds prefer to colonize urban ecosystems having reduced predation pressure. Besides these three species of the present study, Gangajalghati block harbours several other species of heronry birds including Anastomus oscitans, Ardea alba, Ardea intermedia, Ardea cinerea, Ardea purpurea, Bubulcus ibis, Microcarbo niger, Phalacrocorax fuscicollis e.t.c. Studies have reported that these bird species and human can coexist in perfect harmony over long time (Kushlan, 2007). Thus, there is an urgent need to identify and protect potential heronries in different parts of West Bengal as well as India and for that more comprehensive works on these colonial waterbirds at the district or state level are essential and should be supported by nature lovers, ornithologists, local people, government, and non-governmental organisations (Subramanya, 1996).

Usually heronries in close proximity to human habitation are often regarded as a nuisance due to the constant guttural chatter of the nestlings, offensive odours emitted from accumulated droppings, massive amounts of guano, decomposing birds and eggs at the site and the public's perception that heronries may be 
health hazards (Grant and Watson, 1995; Roshnath and Sashikuma, 2019). However, the study found that the local people of the study sites do not regard these activities as a disturbance to their daily life.

Phoenix sylvestris and some other nesting trees of the herons and egrets are scattered throughout the Gangajalghati block. Studies have shown that scattered trees of a terrestrial landscape serve many ecological functions and can act as "keystone structures" for maintaining biodiversity including the heronry birds (Prevedello et al., 2018; Koju et al., 2019). Usually heronry rich sites of India do not harbour Phoenix sylvestris as a dominant species of the study area but the present work has found that Phoenix sylvestris serve as an attractive tree for nesting herons in the scattered heronry sites of Bankura district. Several reasons might be there for this tree preference by the herons in the study area. Phoenix sylvestris can thrive well in a drought prone district like Bankura and a large number of frugivorous birds contribute in their seed dispersal and therefore help in the perpetuation of the species. A large number of Phoenix sylvestris are grown near the water bodies and therefore make an ideal nesting place for the birds. Selection of these trees for breeding reduces the interspecific competition over nest sites as very few other birds choose Phoenix sylvestris for the nesting purpose and these spiny date palms provide cover and protection to the chicks from the predators. Further, many villagers of Gangajalghati block and other parts of the district play a significant role for the protection of the wild date palm trees as they earn their livelihood by collecting sap and producing jaggery items from it.

The existing heronry sites of Gangajalghati block are now under several disturbances of anthropogenic as well as natural origin. Extremely powerful tropical cyclones, severe thunderstorms during the summer months, persistent drought conditions of northern Bankura district, hunting by indigenous tribes, siltation and accumulated sediments in the fish ponds and deforestation nearby wetlands habitats are among the main threats affecting the population of these heronry birds in the study area.

Tropical cyclones produce strong winds, heavy rainfall and high storm surges that result in devastating effects on terrestrial and marine ecosystems by increasing mortality of the flora and fauna (Weimerskirch and Prudor, 2019). More than 150 tropical cyclones have originated over the Bay of Bengal during the past five decades and the South Bengal districts including Bankura have experienced a significant number of such devastating storms (Bhardwaj and Singh, 2020; Mishra and Vanganuru, 2020). The present study documented the effect of Amphan, a powerful and catastrophic tropical super cyclone on the three species of nesting heronry birds at the study area. Amphan was a devastating super cyclone that appeared in the Bay of Bengal since 1999. These severe weather events can exert detrimental effects on breeding waterbirds including heronries affecting their reproductive success or even population size (Hennicke and Flachsbarth, 2009). Being canopy dwellers and sensitive to wind conditions, these birds are particularly vulnerable to the cyclones as they cannot find shelter while experiencing the extreme weather event (Weimerskirch and Prudor, 2019). Several studies have documented the disastrous effects of tropical cyclones on heronries and other nesting birds in India (Taher, 1985; Naik and Parasharya, 1988; Subramanya, 1996; Debata, 2019). Besides cyclones, Nor'westers are very common during the pre-monsoon months (March-May) and are usually accompanied with severe squalls of $130-150 \mathrm{~km} / \mathrm{hr}$ leaving strong negative impacts on bird life and another biota of the region (Litta et al., 2012). Severe thunderstorm and especially the hailstorms exert similar destructive effects on nesting birds causing mass death of hundreds or thousands of birds (Narwade et al., 2014).

Bankura is one of the most drought-prone districts of West Bengal and Gangajalghati block, the study region remains one of the seven drought affected blocks of the district (Bhunia et al., 2020). The district received the maximum number of drought events during at monsoonal period which coincides with the breeding season of these birds (Bhunia et al., 2020). Several previous studies in India have shown that nesting of many heronry birds depends on the availability of water and severe drought events of their habitats lead to failure of nesting in these birds (Ali, 1979; Breeden and Breeden, 1982; Verghese et al., 1982; Ganesh et al., 2014). Drought-driven dry habitats can result in non-availability of food and disturbance at breeding sites in these colonial waterbirds (Ganesh et al., 2014). The regular nesting of the three species was hampered in 2010 which was another severe drought year in Bankura (data not shown). The present study recorded more nesting sites of these birds around pond or wetland associated habitats rather than in flooded agricultural fields. The 
limited availability of nest trees in the agricultural fields might constitute an underlying cause for their abundance near wetland associated habitats (Koju et al., 2019). Further, being a drought affected area in the northern Bankura, the agricultural fields of Gangajalghati rarely remains in a flooded state for long time and therefore offer less food to these piscivorous birds. Construction of a series of small ponds in a drought-prone district like Bankura might help in the conservation of several waterbird species as well as mitigation of the water scarcity problems in the rural areas. Although majority of the heronries in India are found near large water bodies and human habitation (Subramanya, 1996; Chakraborty and Majumder, 2018), the present study recorded a smaller number of heronry nests near Sali Reservoir, the second largest dam in Bankura district. Except a small village (Balidiha) and an ecological park, the dam is mostly surrounded by agricultural fields having sparse vegetation. The ecological park is dominated by Acacia auriculiformis and Eucalyptus sp both of which are usually not preferred as nesting trees by the heronry birds of the area.

Tribal hunting of eggs and nestlings is another serious threat to heronries of the study site. In some of the heronries, local tribal hunters frequently raid the nesting colony for eggs and nestlings. Several studies in India have reported the adverse impact of hunting on heronries and other waterbirds (Nagulu and Ramana Rao, 1983; Ragunatha et al., 1992; Ramachandran et al., 2017).

Another problem for these heronry birds in the study area is siltation and sediment accumulation in some of the ponds near their habitats. These ponds suffer from massive accumulation of organic sediments due to solid waste and unplanned sewage disposal driven by lack of initiatives and financial support from numerous stakeholders of the pond. The anoxic conditions created in such ponds might generate several toxic agents which in turn will reduce the number of fish and other animals used by these waterbirds as their food.

Several trees near the wetlands of the study area have been cut down during the last two decades.

Deforestation and human activity near a heronry may result in decreased food availability, loss of nesting habitat, reduced reproductive success and ultimately may induce abandonment of breeding colonies (Bowman and Siderius, 1984).

\section{Conclusions}

The present study provides a baseline data on nesting trees and habitat preference of three species of heronry birds from Northern Bankura. The study has recorded the importance of Phoenix sylvestris as a nesting tree of these birds in a drought prone district like Bankura. Further, the work has documented for the first time the impact of two tropical cyclones on the nesting of these species. Long term conservation of these scattered heronries of the area might lead to the formation of larger heronries in near future. This can be achieved by preparing a complete inventory of heronries in the district, and constant monitoring of the nesting population, ascertaining their conservation needs, securing suitable breeding habitats with preferred tree species and undertaking a public awareness campaign to stop hunting of these beautiful birds.

\section{Authors' Contributions}

The author read and approved the final manuscript.

\section{Ethical approval}

None of the bird species was captured or killed or subjected to any experimental treatment during the entire period of the study. 


\section{Acknowledgements}

This research received no specific grant from any funding agency in the public, commercial, or not-forprofit sectors. The author would like to express his sincere thanks to Sgt. Anupran Nayak, Sergeant of Indian Air Force, Uttarlai Air Force Station, Barmer, Rajasthan, India and the volunteers of Gangajalghati and Kapista village for their immense help during the fieldwork of this research.

\section{Conflict of Interests}

The author declares that there are no conflicts of interest related to this article.

\section{References}

Ali S (1979). Keoladeo Ghana waterbird Sanctuary. Hornbill 13:27-29.

Ali S, Ripley SD (1987). Compact handbook of the birds of India and Pakistan together with those of Bangladesh, Nepal, Bhutan and Sri Lanka. Oxford University Press, Delhi, pp 737.

Bhardwaj P, Singh O (2020). Climatological characteristics of Bay of Bengal tropical cyclones: 1972-2017. Theoretical and Applied Climatology 139:615-629. https://doi.org/10.1007/s00704-019-02989-4

Bhunia P, Das P, Maiti R (2020). Meteorological drought study through SPI in three drought prone districts of West Bengal, India. Earth Systems and Environment 4:43-55. https://doi.org/10.1007/s41748-019-00137-6

Bowman I, Siderius J (1984). Management guidelines for the protection of heronries in Ontario. Nongame Program, Wildlife Branch, Ontario Ministry of Natural Resources, pp 38.

Breeden S, Breeden B (1982). The drought of 1979-1980 at the Keoladeo Ghana Sanctuary, Bharatpur, Rajasthan. Journal of the Bombay Natural History Society 79:1-37.

Brown CR, Brown MB (2000). Nest spacing in relation to settlement time in colonial cliff swallows. Animal Behaviour 59(1):47-55. https://doi.org/10.1006/anbe.1999.1277

Brown M, Dinsmore JJ (1986). Implications of marsh size and isolation for marsh bird management. Journal of Wildlife Management 50:392-397. https://www.jstor.org/stable/3801093

Brunner I, Herzog C, Dawes MA, Arend M, Sperisen C (2015). How tree roots respond to drought. Frontiers in Plant Science 6:547. https://doi.org/10.3389/fpls.2015.00547

Chakrabarty KK, Nath AK, Sengupta S (2007). Nor'wester over west Bengal and comfortability. Mausam 58(2):177-188.

Chakraborty DC, Majumder S (2018). Urban heronries of Kolkata metropolitan: an insight to nest stratification, resource based guilds and conservation priorities. Asian Journal of Conservation Biology 7(2):106-112.

Chaudhari AB, Chakrabarti K (1973). Wildlife biology of Sundarbans forests. A study of the birds of Sundarbans, with special reference to the breeding of open billed stork, little cormorant and large egret. Science Culture 39:8-16.

Cuervo JJ (2004). Nest-site selection and characteristics in a mixedspecies colony of Avocets Recurvirostra avosetta and Black-winged Stilts Himantopus himantopus. Bird Study 51:20-24. https://doi.org/10.1080/00063650409461328

Das $S$ (2017). Delineation of groundwater potential zone in hard rock terrain in Gangajalghati block, Bankura district, India using remote sensing and GIS techniques. Modeling Earth Systems and Environment 3:1589-1599. https://doi.org/10.1007/s40808-017-0396-7

Das S, Gupta K (2019). Soil survey to support land use/land cover planning in BPS and BPM region in Gangajalghati block, West Bengal, India. Spatial Information Research 27:573-586. https://doi.org/10.1007/s41324-019$00257-1$

Datta T, Pal BC (1990). Space partitioning in relation to nesting among six bird species in the heronry at Kulik Bird Sanctuary, West Bengal. Environment Ecology 8:86-91.

Datta T, Pal BC (1993). The effect of human interference on the nesting of openbill stork Anastomus oscitans at the Raiganj Wildlife Sanctuary, India. Biological Conservation 64:149-154. 
Debata S (2019). Impact of cyclone Fani on the breeding success of sandbar-nesting birds along the Mahanadi River in Odisha, India. Journal of Threatened Taxa 11(14):14895-14898. https://doi.org/10.11609/jott.5480.11.14.14895-14898

Dhua B, Mondal RP, Dutta TK (2013). Study of Anastomus oscitans (Boddaert) population in relation to rainfall and nest formation in Barachaka Village of Bankura District, West Bengal, India. International Journal of Advanced Research 1(9):358-363.

Fogarty DT, Elmore RD, Fuhlendorf SD, Loss SR (2017). Influence of olfactory and visual cover on nest site selection and nest success for grassland-nesting birds. Ecology and evolution 7(16):6247-6258. https://doi.org/10.1002/ece3.3195

Ganesh T, Abhisheka K, Prashanth B (2014). Conservation of Heronries in the Districts of Tirunelveli and Thoothukudi, Southern Tamil Nadu. In: Gopi GV, Hussain SA (Eds). Waterbirds of India. ENVIS Bulletin: Wildlife and Protected Areas, Wildlife Institute of India, Dehradun pp 218-224.

Gopi GV, Pandav B (2011). Nest space partitioning among colonial nesting waterbirds at Bhitarkanika Mangroves, India. World Journal of Zoology 6:61-72.

Grant KR, Watson J (1995). Controlling nuisance egret and heron rookeries in Oklahoma. Great Plains Wildlife Damage Control Workshop Proceedings. 12:32-33. https://digitalcommons.unl.edu/gpwdcwp/435

Grimmett R, Inskipp C, Inskipp T (2011). Birds of the Indian Subcontinent. 2nd Edition. London, Oxford University Press and Christopher Helm, pp 528.

Hennicke JC, Flachsbarth K (2009). Effects of cyclone Rosie on breeding red-tailed tropicbirds Phaethon rubricauda on Christmas Island, Indian Ocean. Marine Ornithology 37:175-178.

Jha KK (2012). Some breeding and ecological aspects of heronry birds at Soor Sarovar Bird Sanctuary Agra, Northern India. Asian Journal of Conservation Biology 1(1):35-41.

Jha S (2006). Kulik-The little known bird paradise. Hornbill 2006(1):26-29.

Kazantzidis S, Goutner V, Pyrovetski M, Sinis A (1997). Comparative nest site selection and breeding success in 2 sympatric Ardeids, Black-crowned Night-Heron (Nycticorax nycticorax) and Little Egret (Egretta garzetta) in the Axios Delta, Macedonia, Greece. Colonial Waterbirds 20(3):505-517.

Kelly JP, D Stralberg, K Etienne, McCaustland M (2008). Landscape influence on the quality of heron and egret colony sites. Wetlands 28:257-275. https://doi.org/10.1672/07-152.1

Koju R, Maharjan B, Gosai KR, Kittur S, Sundar KSG (2019). Ciconiiformes nesting on trees in cereal-dominated farmlands: importance of scattered trees for heronries in lowland Nepal. Waterbirds 42(4):355-453. https://doi.org/10.1675/063.042.0401

Kushlan JA (1993). Colonial waterbirds as bioindicators of environmental change. Colonial Waterbirds 16(2):223-251.

Kushlan JA (2007). Conserving herons, a conservation action plan for the herons of the world. Heron Specialist Group and Station Biologique de la Tour du Valat, Arles, France pp 94.

Law SC (1926). The nesting of open billed stork (Anastomus oscitans) in Purulia, Manbhum District. Journal of the Bombay Natural History Society 31:223-224.

Law SC (1951). A Sunderban heronry. Journal of the Bombay Natural History Society 49:792-793.

Li JY, Li SP, Sun YF, Wu YF, Wu ML (2006). Population dynamics and breeding space niche of four heron species in Tanghai Wetlands. Zoological Research 27(4):351-356.

Litta AJ, Ididcula SM, Mohanty UC, Prasad SK (2012). Comparison of thunderstorm simulations from WRF-NMM and WRF-ARW models over East Indian Region. The Scientific World Journal 2012:1-20. https://doi.org/10.1100/2012/951870

Ma Z, Cai Y, Li B, Chen J (2010). Managing wetland habitats for waterbirds: an international perspective. Wetlands 30:15-27. https://doi.org/10.1007/s13157-009-0001-6

Mishra AK, Vanganuru N (2020). Monitoring a tropical super cyclone Amphan over Bay of Bengal and nearby region in May 2020. Remote Sensing Applications: Society and Environment 20:100408. https://doi.org/10.1016/j.rsase.2020.100408

Mondal RP, Dutta TK, Dhua B (2014). Reporting a new site record of the breeding population of lesser adjutant (Leptoptilos javanicus) from Bankura district, west Bengal, India. International Journal of Current Research 6(1):4441-4443.

Mukherjee AK (1959). Pakhiral, Sajnakhali-An introduction to a bird sanctuary in the Sunderbans. Journal of Bengal Natural History Society 30:161-165. 
Mukhopadhyay A (1980). Some observation on the biology of the Openbill Stork Anastomus oscitans Boddaert in southern Bengal. Journal of the Bombay Natural History Society 77:131-137.

Nagulu V, Ramana Rao JV (1983). Survey of south Indian pelicanries. Journal of the Bombay Natural History Society 80:141-143.

Naik RM, Parasharya BM (1988). Impact of the food availability, nesting-habitat destruction, and cultural variations of human settlements on the nesting distribution of a coastal bird, Egretta gularis, in Western India. Journal of the Bombay Natural History Society 84:350-360.

Narayanan SP, Sreekumar B, Vijayan L, Thomas AP (2012). Status of the nests of near-threatened oriental darter Anhinga melanogaster at Kumarakom heronry. National Academy Science Letters 35:99-101. https://doi.org/10.1007/s40009-012-0027-9

Narwade S, Gaikwad MC, Fartade K, Pawar S, Sawdekar M, Ingle P (2014). Mass mortality of wildlife due to hailstorm in Maharashtra, India. Bird Populations 13:28-35.

Nayak A (2019). Bar-headed goose: first record of migratory Anser indicus in Gangdua Dam of Bankura District, West Bengal, India. Zoo's Print 34(3):28-31.

Nayak A (2020). Blue rock-thrush Monticola solitarius pandoo : First record from the southern West Bengal, India. Ela Journal of Forestry and Wildlife 9(2):657-661.

Podkowa P, Surmacki A (2017). The importance of illumination in nest site choice and nest characteristics of cavity nesting birds. Scientific reports 7(1):1329. https://doi.org/10.1038/s41598-017-01430-y

Pramanik A, Santra K, Manna C (2009). Nest-building behaviour of the Asian open billed stork Anastomus oscitans, in the Kulik Bird Sanctuary, Raiganj, India. Our Nature 7(1):39-47. https://doi.org/10.3126/on.v7i1.2552

Pramanik AK, Santra KB, Manna CK (2014). Seasonal abundance and factors influencing the population of Asian openbilled stork (Anastomus oscitans) in the Raiganj wildlife sanctuary, West Bengal, India., Asian Journal of Conservation Biology 3(1):28-37.

Pramanik AK, Santra KB, Manna CK (2016). Some Observations on breeding behaviour of the Asian open-billed stork (Anastomus Oscitans) in the Raiganj Wildlife sanctuary, West Bengal, India. International Research Journal of Environmental Sciences 5(9):10-21.

Prevedello JA, Almeida-Gomes M, Lindenmayer DB (2018). The importance of scattered trees for biodiversity conservation: A global meta-analysis. Journal of Applied Ecology 55:205-214. https://doi.org/10.1111/13652664.12943

Ragunatha V, Subramanya S, Shyamal L, Lokesh R, Vasudeva R (1992). A preliminary survey of Gudvi bird sanctuary. My Forest 28:265-274.

Ramachandran R, Kumar A, Gopi Sundar KS, Bhalla RS (2017). Hunting or habitat? Drivers of waterbird abundance and community structure in agricultural wetlands of southern India. Ambio 46(5):613-620. https://doi.org/10.1007/s13280-017-0907-9

Roshnath R, Athira K, Sinu PA (2019). Does predation pressure drive heronry birds to nest in the urban landscape? Journal of Asia-Pacific Biodiversity 12:311-315. https://doi.org/10.1016/j.japb.2019.02.007

Roshnath R, Sashikuma C (2019). Conservation challenges of the heronries in Kerala. Journal of the Bombay Natural History Society 116:63-67.

Roshnath R, Sashikumar C, Vishnudas CK, Palot J, Raju S, Mannar H, ... Meppayur S (2017). Heronries of Kerala, 2015. A summary of the heronry census. Malabar Trogon 15:35-40.

Roshnath R, Sinu PA (2017). Nesting tree characteristics of heronry birds of urban ecosystems in peninsular India: implications for habitat management. Current Zoology 63(6):599-605. https://doi.org/10.1093/cz/zox006

Scheffer M, van Geest GJ, Zimmer K, Jeppesen E, Søndergaard M, Butler M, ... Persson L (2006). Small habitat size and isolation can promote species richness: second-order effects on biodiversity in shallow lakes and ponds. Oikos 112:227-231. https://doi.org/10.1111/j.0030-1299.2006.14145.x

Sharma A (1998). Tamed Asian openbill storks Anastomus oscitans in Kulik bird sanctuary, Raiganj, North Dinajpur district of West Bengal. Newsletter for Birdwatchers 38 (4):37.

Sharma A (2001). In the land of Asian openbill. Environment 8(2):59-61.

Sharma A (2004). Birding at Raiganj Bird Sanctuary, North Dinajpur district in West Bengal. Newsletter for Birdwatchers 44(6):89-90.

Sharma A (2007a). Asian openbill-storks Anastomus oscitans of Raiganj Bird Sanctuary, Uttar Dinajpur district, West Bengal. Indian Birds 3(3):94-96. 
Sharma A (2007b). Some birds of Kulik Bird Sanctuary, North Dinajpur district, West Bengal. Newsletter for Birdwatchers 47(2):22-24.

Sridhar S (2004). The rise and fall of Raiganj Bird Sanctuary. Newsletter for Birdwatchers 44(6):82-83.

Subramanya S (1996). Distribution, status and conservation of Indian heronries. Journal of the Bombay Natural History Society $93(3): 459-486$.

Subramanya S (2005). Heronries of Tamil Nadu. Indian Birds 1(6):126-140.

Taher SA (1985). Nellapattu and Pulicat Bird Sanctuaries in Andhra Pradesh after the November, 1984 cyclone. Mayura 6(1-4):21-25.

Verghese A, Chakravarthy AK, Bhatnagar RK (1982). Bird life in Ghana Bird sanctuary, Bharatpur (India), before and after the 1979 drought. Cheetal 23:13-23.

Weimerskirch H, Prudor A (2019). Cyclone avoidance behaviour by foraging seabirds. Scientific Reports 9:5400. https://doi.org/10.1038/s41598-019-41481-X
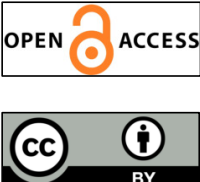

The journal offers free, immediate, and unrestricted access to peer-reviewed research and scholarly work. Users are allowed to read, download, copy, distribute, print, search, or link to the full texts of the articles, or use them for any other lawful purpose, without asking prior permission from the publisher or the author.

License - Articles published in Notulae Scientia Biologicae are Open-Access, distributed under the terms and conditions of the Creative Commons Attribution (CC BY 4.0) License.

(c) Articles by the authors; SHST, Cluj-Napoca, Romania. The journal allows the author(s) to hold the copyright/to retain publishing rights without restriction. 